\title{
АНТИБІОТИКИ ТА АНТИБІОТИКОРЕЗИСТЕНТНІ ВЛАСТИВОСТІ МІКРООРГАНІЗМІВ МОЛОКА
}

\section{В. Данчук ${ }^{l}$, В. Трач ${ }^{2}$, Т. Приступа, М. Клюцук, В. Добровольський ${ }^{2}$, Л. Савчук ${ }^{2}$} А. Левченко ${ }^{3}$, О. Данчук ${ }^{3}$

${ }^{1}$ Наиіональний університет біоресурсів і природокористування України

${ }^{2}$ Подільський державний аграрно-технічний університет

${ }^{3}$ Одеський державний аграрний університет

В огляді представлено науково-обтрунтовані дані щзодо ризиків, пов'язаних із споживанням та переробкою молока контамінованого антибіотиками та антибіотикорезистентними штамами мікроорганізмів.

Ключові слова: антибіотики, антибіотикорезистентність, молоко.

Технологія виробництва якісного молока-сировини залежить від багатьох факторів, які можна узагальнити у дві великі групи, пов'язані зі здоров'ям та продуктивністю дійного стада, 3 одного боку, а з іншого - технологією його одержання $[1,2]$. Виробництво молока і молочних продуктів $€$ однією з категорій національної безпеки і тому держави займаються довгостроковим прогнозуванням показників молочного виробництва та контролю якості продукції [3, 4].

Мікробне забруднення молока-сировини залежить від багатьох факторів, серед яких варто виділити наступні (Рис. 1): здоров'я молочної залози; гігієна доїльної зали та обладнання; інтенсивність утворення біоплівок; технологія утримання корів; температура молока, тривалість зберігання; використання антибіотиків та поширення генів антибіотикорезистентності; профілактичні заходи та вибраковка корів. Кожен із зазначених факторів істотно впливає на безпеку молочного продукту, однак поширення антибіотиків у довкіллі та через харчові продукти є однією з глобальних проблем людства [5].

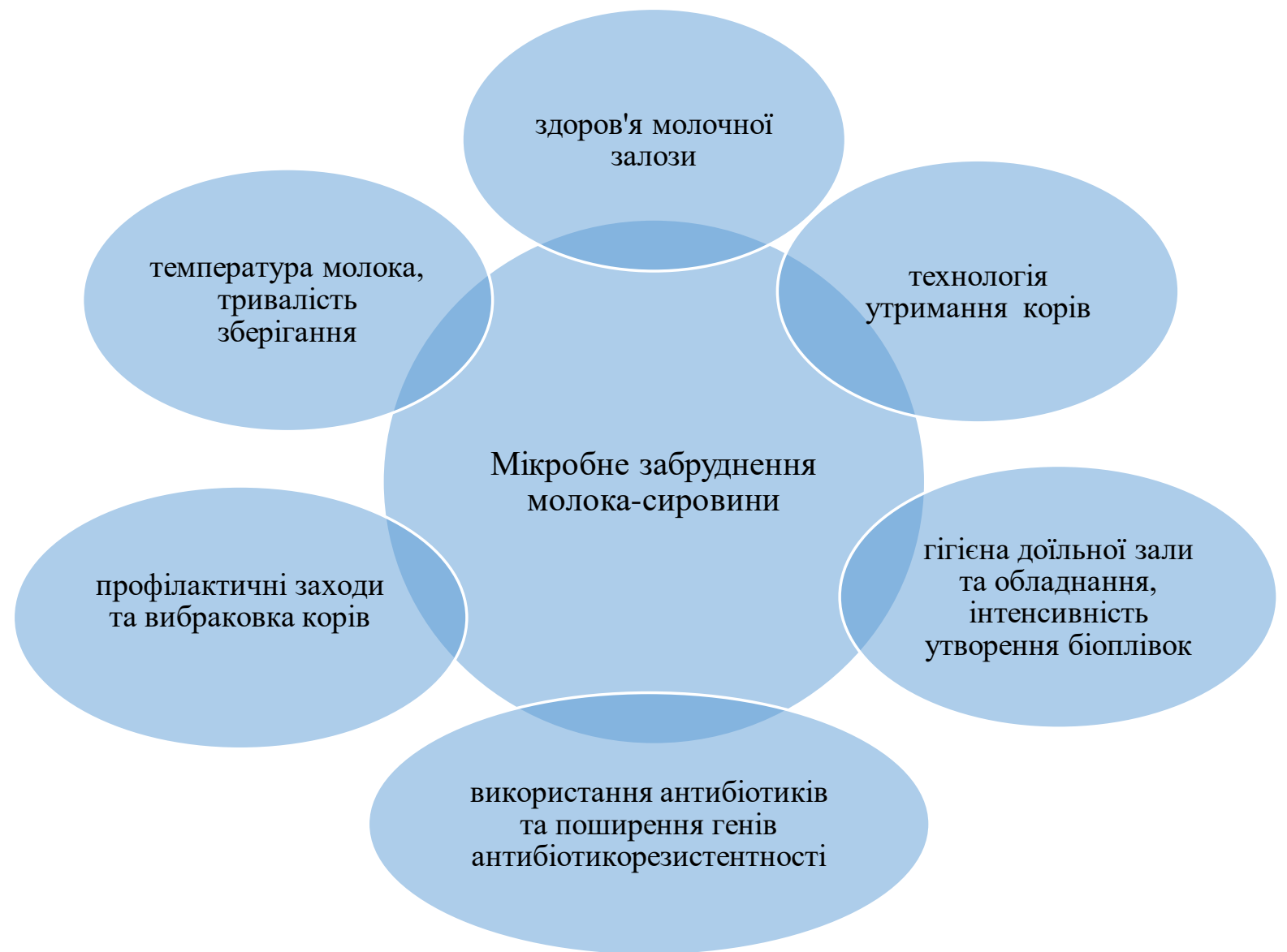

Рисунок 1. Фактори регуляції мікробного забруднення молока-сировини. 
Дане питання уже обговорюється на різних рівнях, і якщо хтось думає, що молоко пастеризується і загроза таким чином нівелюється то це не так. По-перше молоко (молозиво) випоюють телятам і заселяють резистентними мікроорганізмами їх травний тракт. По-друге виготовлення не усіх молочних продуктів передбачає пастеризацію молока, особливо в домашніх умовах. І по третє - вдосконалення захисних адаптивних механізмів патогенних мікроорганізмів завжди негативно відбивається на лікуванні людей, враховуючи існуючі моделі міграції антибіотикорезистантних властивостей.

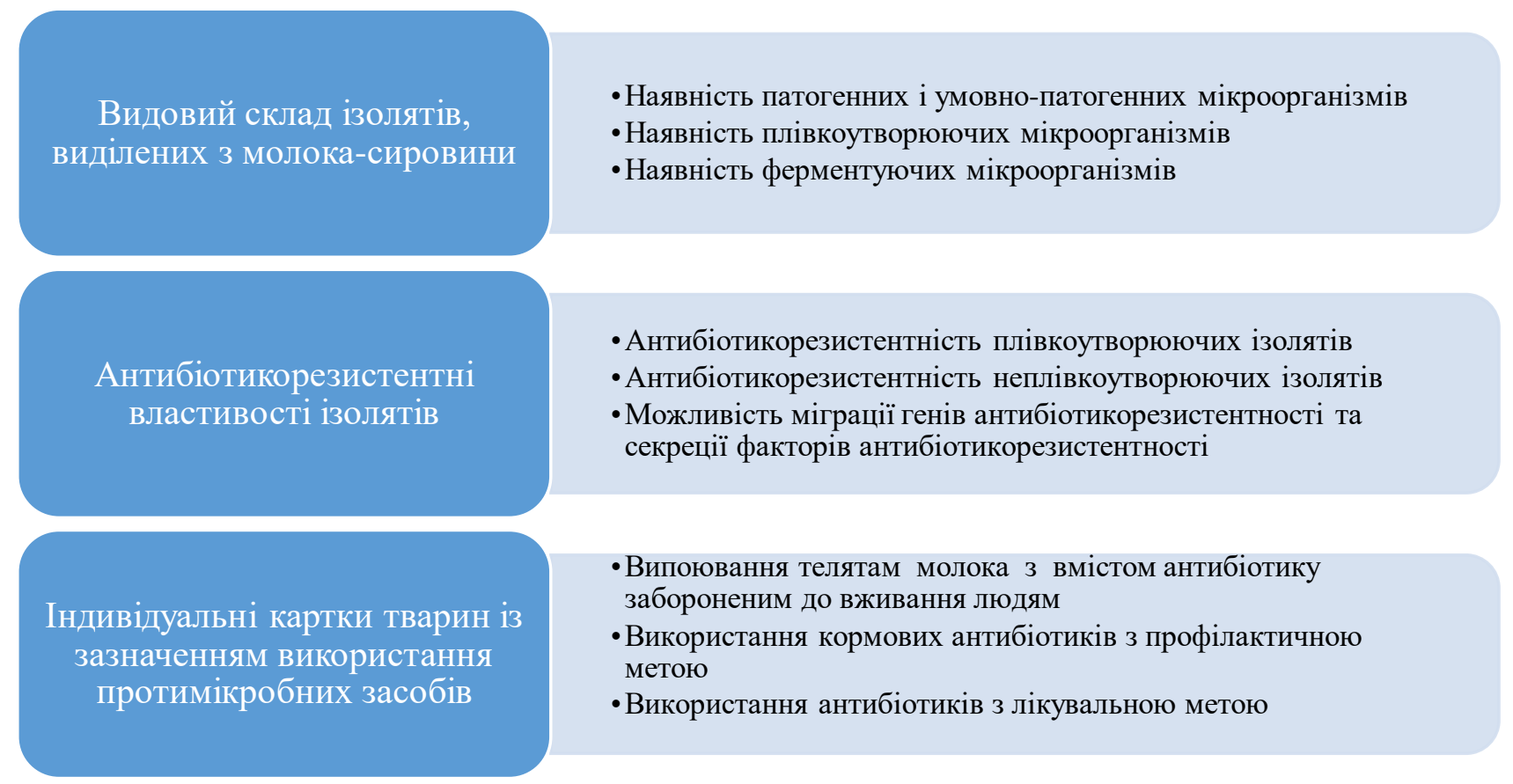

Рисунок 2. Фактори, що впливають на ефективність лікування хвороб молочної залози та показники біологічної безпеки.

Використання антибіотиків у виробництві молока-сировини істотно впливає на біологічну безпеку одержаного продукту (Рис. 2). Більшість протимікробних препаратів, що використовуються для лікування корів, призводять до того, що молоко цих тварин утримується 3 продажу (відходи молока) через наявність залишків ліків, що перевищують концентрацію допуску, встановлену Управлінням з контролю за продуктами та ліками США (FDA). Рівень допуску - це концентрація, що визначається FDA, при якій залишки речовини, присутні в харчовому продукті, не матимуть шкідливого впливу на його споживачів [6]. Дослідження показали, що протимікробні препарати при концентраціях нижче мінімальної інгібуючої концентрації (суб-МІК) можуть стимулювати мутагенез і рекомбінацію, що призводить до адаптації бактерій до різних стресів, включаючи антимікробний тиск [7].

Окремі дослідники відзначають, що телята, яких годували молоком 3 додаванням протимікробних препаратів у дуже низьких концентраціях, мали значно вищу частку ізолятів, стійких до трьох $\beta$-лактамів, препарату аміноглікозидів та тетрацикліну, порівняно з телятами, яких годували молоком без додавання ліків [8].

Проведення профілактичних заходів, визначення стану здоров'я молочної залози та використання антибіотиків у молочному скотарстві потребує особливого контролю у виробництві молока-сировини. Як свідчить досвід розвинутих держав, профілактично-лікувальну обробку дійних корів протимікробними засобами переважно планують у сухостійний період. Але тут виокремлюється два підходи: поголовна обробка, не залежно від результатів тестування на субклінічну форму маститу та вибіркова обробка хворих тварин. Експерти у розвинутих країнах розробили рекомендації щодо лікування маститу молочних корів. Ці рекомендації доповнюють правові норми щодо відпуску антибіотиків та містять практичні вказівки щодо використання антибіотиків у терапії маститу [9]. 
Навіть у промислово-розвинених країнах ураження харчовими токсикоінфекціями через споживання неякісного молока та молочних продуктів становлять від $2 \%$ до 6\% від усіх зареєстрованих випадків захворювань через отруєння харчовими продуктами [10].

Ферментні системи молока тваринного і мікробіального походження (біоплівки) досить часто заважають створити якісний молочний харчовий продукт [11]. Чим нижча культура отримання молока-сировини, тим більше спостерігається ізолятів, здатних утворювати стійкі біоплівки [12].

Світова практика жорстко регламентує придатність молока-сировини для його технологічної переробки за багатьма показниками, в тому числі і за кількістю бактерій та соматичних клітин [13]. На даному етапі розвитку молокопереробної галузі вводяться спеціальні тести для визначення кількості індикаторних бактерій не тільки у молоці-сировині що поступає на виробництво, але і на різних його етапах, до одержання кінцевого продукту. Індикаторні мікроорганізми - це бактерії, які є показниками неналежної гігієни виробництва, обробки або забруднення харчових продуктів на кінцевому етапі [14].

Підтримання здоров'я лактуючих тварин $є$ ключовим питанням у одержанні якісного продукту, проте досить часто процес передбачає використання лікарських засобів з вираженою протимікробною дією, що унеможливлює на певний період не тільки для використання молока і молочної продукції, але і створює передумови для утворення антибіотикорезистентних мікроорганізмів та розповсюдженні генів антибіотикорезистентності у довкіллі [15-17].

Закономірності поширення антибіотиків 3 молоком лише віддалено можуть нагадувати аналогічне поширення мікотоксинів [18], але є істотні відмінності загроз. По перше - людина свідомо виробляє і використовує дані лікарські засоби і тому $є$ можливість робити то контрольовано та планомірно, а по-друге - 3 поширенням антибіотиків у довкіллі одночасно зростає і поширення генів антибіотикорезистентності, і в даному ключі молоко-сировина $\epsilon$ потужним джерелом їх міграції [19].

Як тільки було відкрито антибіотики, за деякий час, у сирому молоці було встановлено перші антибіотикорезистентні штами мікроорганізмів, хоча інспекція товарних ферм і не виявила взаємозв'язків між використанням антибіотиків та антибіотикорезистентними властивостями мікроорганізмів досліджуваних зразків молока [20]. Очевидно це пов'язано з використанням у ветеринарній медицині на той час антибіотиків природного походження, а наявність природної резистентності мікроорганізмів була мало вивчена.

Спеціалістами 3 ветеринарної медицини у тваринництві використовується понад 150 антибіотиків, і $90 \%$ цих антибіотиків є природними продуктами бактерій, грибів та напівсинтетичних речовин, отриманих у результаті модифікації природних сполук, а деякі з них $\epsilon$ синтетичними [21]. Встановлено, що залишки антибіотиків не тільки впливають на якість та безпеку молочної продукції, зокрема сирів, але i сприяють поширенню антибіотикорезистентності мікроорганізмів [22].

На процес виробництва сиру наявність антибіотиків у сировині, зокрема, енрофлоксацину може і не впливати, хоча його вміст у продукті може залишатись стабільним тривалий час [23]. Окремо наголошується на важливості оцінки безпеки кожного ізоляту, призначеного для ферментації молочної продукції, стосовно його біологічних характеристик, вірулентності та антибіотикорезистентних властивостей [24].

Окрім ризиків, пов'язаних із споживанням молока-сировини, є сумніви щодо безпеки сирів, виготовлених з такого молока. Хоча сир і можна безпечно виготовляти з молока-сировини, проте існували спалахи харчових токсикоінфекцій, пов'язаних з молочними сирами, спричинених кишковою паличкою [25-29].

Антибіотикорезистентність мікроорганізмів молока $\epsilon$ важливою передумовою їх виживання, природною властивістю, одним з механізмів адаптації, і не обов'язково результатом короткотривалого застосування тих чи інших терапевтичних засобів 3 лікувальною метою лактуючому організму. Відсутність набутої стійкості до антимікробних препаратів стала важливим критерієм оцінки біобезпеки лактобактерій, що використовуються як промислові закваски або пробіотичні культури [30]. 
Грудне молоко людини характеризується великим бактеріальним біорізноманіттям (понад 200 різних видів бактерій) [31-32]. Вважається, що немовля отримує близько $10^{5}-$ $10^{7}$ коменсальних бактерій через грудне молоко на добу [33].

Дослідження на людському молоці та молозиві показали, що вони мають унікальну бактеріальну популяцію, яка колонізує травний тракт немовляти і може генотипово відрізнятись від тих штамів, що виділяються зі шкіри та фекалій [34-36].

Виділені ізоляти Lactobacillus з грудного молока людини володіють антибактеріальними властивостями [37-38] та проявляють досить високий рівень антибіотикорезистентності [39].

Людське молоко містить специфічну мікробіоту і забезпечує постійне надходження коменсальних та потенційно пробіотичних бактерій до травного тракту немовлят [40]. За таких умов на передній план виходять пробіотики, одержані з використанням підходів синтетичної біології [41].

Staphylococcus epidermidis, потрапляючи в травний тракт у грудних дітей, також має і пробіотичну функцію, запобігаючи колонізації їх організму патогенами, такими як Staphylococcus aureus [42]. Однак, даний мікроорганізм може бути i патогенним. Staphylococcus epidermidis, виділений із зразків калу немовлят, може мати високий рівень антибіотикорезистентності до антибіотиків класу макролідів та аміноглікозидів [43-44].

У молоці-сировині та молочних продуктах (сири, йогурти та інші), лактобактерії природньо присутні або додаються навмисно з технологічних причин і можуть володіти досить широким спектром біологічних властивостей, до яких відноситься i передача генів антибіотикорезистентності за допомогою плазмід [45].

Йогурт - це продукт на основі молока, виготовлений методом молочнокислого бродіння, яке супроводжується синтезом коротколанцюгових жирних кислот, зниженням $\mathrm{pH}$, створюючи таким чином несприятливі умови для розвитку збудників харчових токсикоінфекцій [46]. Дослідження штамів Lactobacilli, виділених з монгольського йогурту виявило полірезистентність до антибіотиків різних класів (канаміцину, тетрациклу, ампіциліну, хлорамфеніколу, натрію цефокситину, гентаміцину, поліміксину В, налідиксовій кислоти, метронідазолу). У свою чергу, виділені лактобактерії здатні синтезувати плантарицин і є добрими пробіотиками [47].

Крім того, повідомляється, що у йогуртах паралельно можуть виявлятись деякі потенційні патогени людини, які володіють гемолітичними властивостями та стійкістю до до $\beta$-лактамних антибіотиків [48].

Антибіотикорезистентність патогенних мікроорганізмів стає дедалі більшою проблемою і набуття ії ознак істотно обмежує ефективний термін використання нових протимікробних сполук (лише 10-20 років). Крім того, навряд чи нові ефективні протимікробні засоби будуть розроблені 3 достатньою швидкістю [49-50]. Тому, перед людством стоїть головна проблема - створити альтернативні шляхи боротьби з бактеріальними збудниками, або знайти та впровадити у технологію виробництва харчових продуктів тваринного походження способи затримки поширення генів стійкості до антибіотиків у довкіллі, у тому числі і з молоком-сировиною та молочними продуктами [51].

Існує великий ризик того, що гени антибіотикорезистентності, накопичені мікроорганізмами, що контамінують лактуючих ссавців, у відповідь на велику кількість антибіотиків, що використовуються у медицині та тваринництві, можуть передаватися мікробіоті людини через грудне молоко та продукти тваринного походження. Таке розповсюдження генів антибіотикорезистентності може значно вплинути на ефективність антибіотикотерапії та призвести до появи нових патогенних штамів, стійких до багатьох антибактеріальних засобів [52].

Безумовно, що передача генів можлива лише за декількох критичних умов: можливість забезпечити передачу зі сторони донора гену та відповідна можливість сприйняття рецепієнтом гену; досягненні певної критичної віддалі між учасниками процесу; наявність відповідного рівня метаболічного забезпечення процесу передачі гену антибіотикорезистентності; забезпечення можливості інтеграції гену антибіотикорезистентності в геном рецепієнта [52].

Провідні держави Європи останніми роками починають досліджувати дійне поголів'я великої рогатої худоби на наявність мультирезистентних штамів патогенних та чутливість умовно патогенних мікроорганізмів до антибіотиків [53]. Також на національному рівні в окремих 
державах розпочато моніторинг використання протимікробних засобів на молочних фермах та визначення антибіотикорезистентності ізолятів виділених з молока дійних корів [54-55].

Поширення генів антибіотикорезистентності 3 молоком-сировиною на прикладі Staphylococcus epidermidis та E. coli. Рід Staphylococcus включає більше 19 видів, 3 них тільки 3 види екологічно пов'язані з організмом людини: St. aureus, St. epidermidis, St. saprophiticus. Раніше вважалось, що St. epidermidis не виробляє агресивних токсинів [56]. Однак, пізніше було доведено протизапальну та цитолітичну дію токсинів St. epidermidis, які сприяють розвитку сепсису [57]. St. epidermidis, що колонізує поверхню шкіри та слизових органів раніше вважався не патогенним, проте він також може виступати в ролі збудника субклінічної форми маститу, як і E. coli. Отже, St. epidermidis $є$ серйозною проблемою у молочному скотарстві, і вважається одним з основних етіологічних агентів маститів овець [58].

Однією з важливих відмінностей St. epidermidis є його здатність утворювати біоплівку (англ. Biofilm), а саме - структурне співтовариство мікроорганізмів, інкапсульованих у саморозвиненому полімерному матриксі, розташованому на біотичній чи абіотичній поверхні [59].

Молочні біоплівки, як джерело забруднення молока та його продуктів, викликають велике занепокоєння у молочній галузі. Для надійної оцінки існуючих ризиків необхідно поглиблювати знання про мікробний склад біоплівки у доїльних системах молочних ферм. При чому, E. coli досить часто виявляється у біоплівках на молочному обладнанні доїльних ферм, в основному на фіксаторах доїльного обладнання та випускній системі резервуару для молока [60].

3 молока-сировини досить часто виділяються штами Staphylococcus epidermidis та E. coli, які володіють абсолютно різними біологічними властивостями та чутливістю до протимікробних засобів. То є дві різні стратегії виживання мікроорганізмів до дії несприятливих факторів, хоча $\mathrm{i}$ не виключають їх взаємодоповнення та взаємопоглинання (Рис. 3).

Так, для Staphylococcus epidermidis притаманне: утворення біоплівки та наявність глікокалісу (глікопротеїни та полісахариди); затримка, інактивація та виведення з біоплівки антибіотиків; сповільнення росту бактерій біоплівки; низька чутливість до антибіотиків (10001500 разів нижча); секреція та утримування у біоплівці захисних речовин, що забезпечують антибіотикорезистентність; перенесення генів антибіотикорезистентності, передача сигналів, міжклітинні, міжвидові комунікації [61-67].

Більшість штамів кишкової палички є нешкідливими коменсальними організмами; проте еволюціонували і їі патогенні штами, які відповідають за різні типи клінічних захворювань у людей і тварин [68]. Що стосується бактерії E. coli, на рисунку 3 узагальнено іiі наступні властивості: відсутність автономної здатності утворювати біоплівки, покриття виключно поодиноких клітин; контакт антибіотику проходить безпосередньо 3 поверхнею бактерії; інтенсивний ріст мікроорганізмів у сприятливому середовищі; висока чутливість до антибіотиків; секреція в оточуюче середовище захисних речовин з високою ймовірністю їх міграції у просторі; низький рівень міжклітинних взаємодій [69-73].

На сьогодні одним із найскладніших захворювань, з якими стикаються виробники молокасировини та яловичини, крім маститів, є колібактеріоз - ураження органів травного тракту, яке наносить значні фінансові збитки. Ентеротоксигенні штамами E. coli виробляють термостабільні ( $\mathrm{STa}$ або STb) та / або термостійкі (LT) ентеротоксини. $€$ багато повідомлень про виділення та ідентифікацію патогенів кишкової палички (ентероагрегативної кишкової палички (EAEC); шига-токсин продукуючої E. coli (STEC); ентеропатогенної E. coli (EPEC); ентеротоксигенної E. coli (ETEC); дифузно-адгерентні E. coli (DAEC)) у випадках діареї немовлят, а також молодих тварин [74].

Штами кишкової палички, виділені 3 молока та молочних продуктів, мали високу поширеність інтіміну (eaeA), токсинів Vero або Shiga (vtxl та vtx2 або stxl та stx2) та гемолізину ( hlyA). Ці фактори можуть спричинити бактеріальну адгезію та інвазію в епітеліальні клітини кишок [75-77].

Виникнення харчових токсикоінфекцій, спричинених цією бактерією, в основному відбувається завдяки активності певних О-серогруп, включаючи не-О157 (O103, О26, О113, О91, O145, O111, O121, O128 і O45), а також O157 [78-80]. 
Штами STEC, в основному, стійкі до кількох типів антибіотиків. Документовані дані показали, що штами STEC, виділені з молока та молочних продуктів, а також інших типів харчових зразків мали високу поширеність стійкості до різних типів антибіотиків, включаючи аміноглікозиди, фторхінолон, тетрацикліни, триметоприм, ампіцилін, цефалотин, сульфаніламіди, гентаміцин та хлорамфенікол [81-83].

\section{Біоплівка}

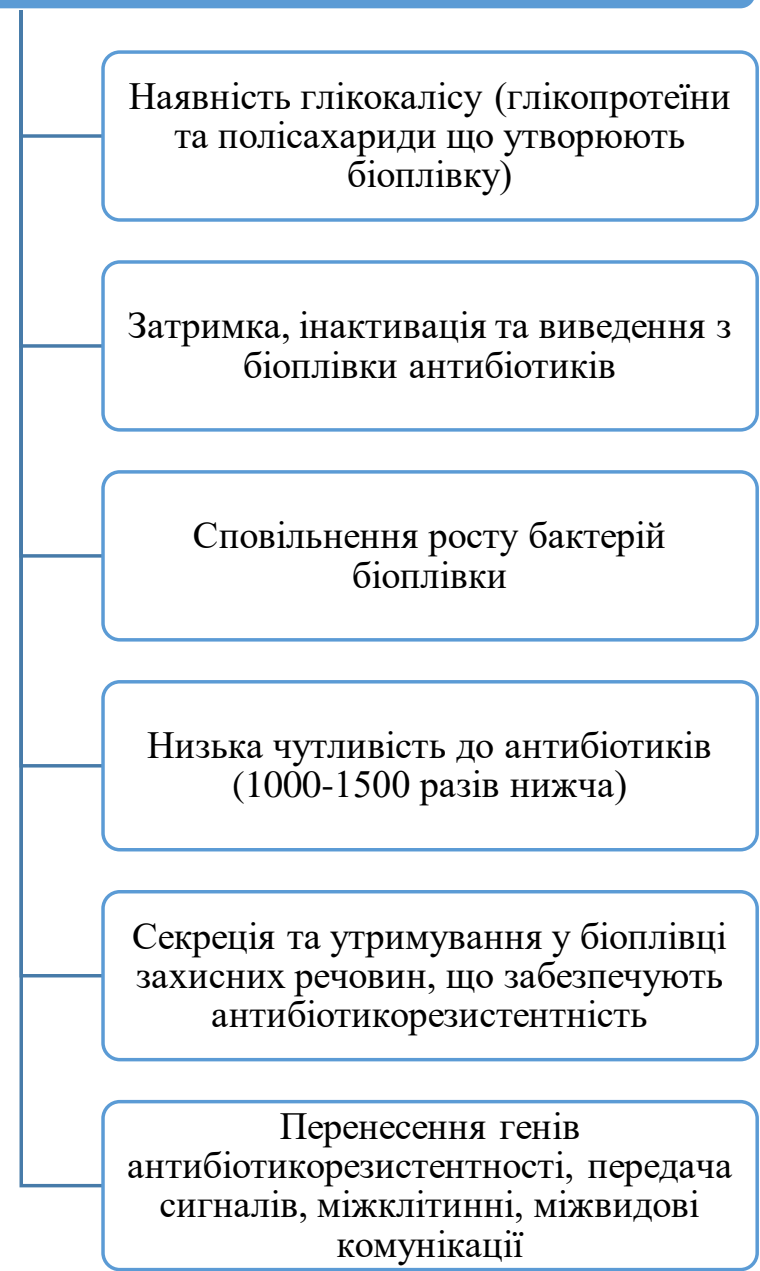

Бактерія

Відсутність біоплівки, покриття виключно поодиноких клітин

Контакт антибіотику безпосередньо 3 поверхнею бактерії

Інтенсивний ріст мікроорганізмів у сприятливому середовищі

Висока чутливість до антибіотиків

Секреція в оточуюче середовище захисних речовин з високою ймовірністю їх міграції у просторі

Низький рівень міжклітинних взаємодій

Рисунок 3. Порівняльна характеристика мікроорганізмів біоплівки та окремих бактерій

Молекулярні епідеміологічні дослідження показали, що наявність певних генів стійкості до антибіотиків, включаючи гени, що кодують стійкість до фторхінолону $(Q N R)$, триметоприм $(d f r A l)$, цефалотина (blaSHV), тетрациклін (дельта і tetB), ампіцилін (CITM), гентаміцин (AAC (3)$I V)$, сульфонамід (sull), хлорамфенікол (catl i cmlA), аміноглікозиди (aadAl), а еритроміцин (ereA) є найважливішою причиною появи стійкості до антибіотиків у штамів STEC [84-86].

Гени антибіотикорезистентності можуть виникати de novo або передаватися шляхом трансформації, кон'югації або трансдукції [87]. У горизонтальному перенесенні генів антибіотикорезистентності беруть участь плазміди, бактеріофаги та інші мобільні елементи [88]. Внесок кожного з цих шляхів поширення антибіотикорезистентності на даний момент неясний. 
<smiles>O=C(N[C@@H](CO)[C@H](O)c1ccc([N+](=O)[O-])cc1)C(Cl)Cl</smiles><smiles>CC(=O)OC[C@H](NC(=O)C(Cl)Cl)[C@H](O)c1ccc([N+](=O)[O-])cc1</smiles>
C

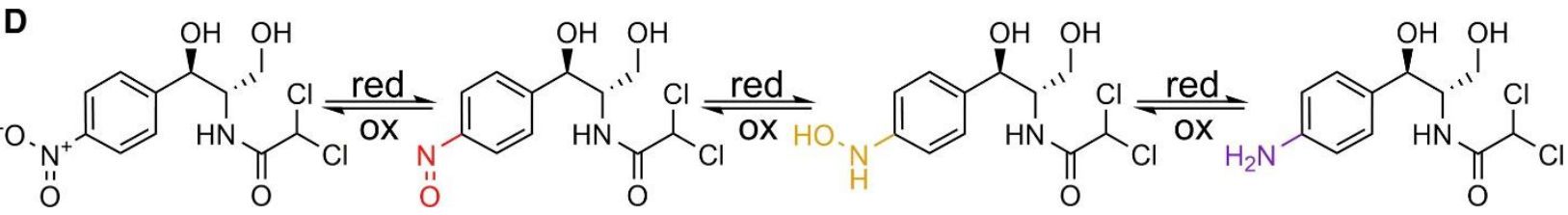

Рисунок 4. Будова хлорамфеніколу та його похідних (A - C) Хімічна структура (A) хлорамфеніколу, (В) хлорамфеніколу, інактивованого після ацетилювання, та (C) хлорамфеніколу, інактивованого після нітроредукції (D)

Продукти поетапного відновлення хлорамфеніколу зліва направо: левоміцетин, нітрозохлорамфенікол, гідроксиламінохлорамфенікол та амінохлорамфенікол [88].

Як свідчать результати досліджень антибіотикорезистентних властивостей ізолятів $E$. coli, виділених з молока-сировини, одержаного від клінічно здорових корів, відсутність чутливості бактерій до хлорамфеніколу була притаманна трохи більше $30 \%$ ізолятів, натомість решта були чутливими. Зовсім іншими параметрами антибіотикорезистентності характеризуються ізоляти E. coli з молока корів хворих на субклінічну форму маститу. Так, більше 60 \% виділених ізолятів були резистентними до антибіотику і трохи більше 30 \% - чутливими. У ізолятів, виділених при ендометриті ця пропорція склала 50/50. Отже, 3 молока корів, що утримуються в одному і тому ж тваринницькому приміщенні виділяються ізоляти E. coli з різною чутливістю до хлорамфеніколу, при чому в молоці-сировині від здорових корів цей показник $\epsilon$ вищим у 2 рази, порівняно до молока від корів з субклінічною формою маститу.

Тетрацикліни $є$ природними продуктами вторинного метаболізму актиноміцетів і, ймовірно, існують у навколишньому середовищі мільйони років. У випадку патогенних мікроорганізмів для людини резистентність до тетрацикліну, як правило, набувається шляхом горизонтального переносу генів і відбувається майже виключно за допомогою рибосомного захисту або відтоку антибіотиків. Tet $(\mathrm{X})$ - це флавопротеїнова монооксигеназа, яка інактивує тетрациклінові антибіотики шляхом моногідроксилювання 3 наступним спонтанним, неферментативним розпадом.

Захист від рибосом і витікання лікарського засобу не впливають на концентрацію або активність самої молекули тетрацикліну, що відрізняє клінічну стійкість до тетрацикліну від стійкості до аміноглікозидів, амфеніколу та $\beta$-лактаму природного продукту, які зазвичай інактивуються ферментативно [89].

Натомість тетрациклін, механізм дії якого пов'язаний зі зв'язуванням 16S pРНК [90], показав, що ефективність захисних механізмів ізолятів E. coli з молока-сировини $\epsilon$ високою (80\%резистентні, 20-чутливі). При чому, аналогічна картина спостерігалась і у бактерій, виділених 3 секрету молочної залози, ураженої субклінічною формою маститу. А ізоляти з піхви хворих тварин були повністю резистентні до даного протимікробного засобу. Отже, механізмом опору дії тетрацикліну за принципом витікаючого насоса у E. coli є досить ефективним [91].

Нітрофурантоїн $\quad((E)-1$-[(5-nitro-2-furyl)methylideneamino]imidazolidine-2,4-dione $)$ протимікробний лікарський засіб групи нітрофурану. Механізм дії спрямований на інгібування бактеріальних ферментів, що беруть участь у синтезі вуглеводів, а у більш високій концентрації ДНК, РНК та синтезу білка шляхом дії на бактеріальні рибосомні білки [92]. Стійкість до мікроорганізмів до нітрофурантоїну $є$ рідкісна, що робить його важливим препаратом для лікування інфекцій сечовивідних шляхів, стійких до поширених та крайніх засобів антибіотиків, таких як цефалоспорини, фторхінолони, аміноглікозиди та карбапенеми. Резистентність до NFT 
в основному опосередковується мутаціями nfsA та / або $\mathrm{nfsB}$, обидві кодують нечутливі до кисню нітроредуктази, відповідальні за високу стійкість до нітрофурантоїну [93-94].

Гени стійкості до нітрофурантоїну оqхА та оqхВ. Ї̈ї активна форма генерується в бактерії під дією ферментів нітроредуктази, які відновлюють нітрогрупу, приєднану до фуранового гетероциклічного кільця, породжуючи активні проміжні метаболіти, які пригнічують синтез білків, що беруть участь у метаболізмі ДНК, РНК та вуглеводів. Стійкість до нітрофурантоїну в E. coli втраті внутрішньоклітинної активності нітроредуктази через послідовні мутації в генах nfsA та nfsB, що кодують нечутливі до кисню нітроредуктази [95].

Фторхінолони являють собою похідні 4-хінолону, які містять у положенні 7 хінолінового ядра не заміщений або заміщений піперазиновий цикл, а у положенні 6 - атом фтору. За кількістю атомів фтору в молекулі фторхінолони розподіляються на монофторхінолони, дифторхінолони та трифторхінолони. Фторхінолони діють бактерицидно, порушуючи синтез ДНК в бактеріальних клітинах, блокуючи два життєвоважливих ферменти бактерій - ДНК-гідразу та топоізомеразу. За часом створення препарати цієї групи розподіляються на 4 покоління. До препаратів I покоління належать норфлоксацин, офлоксацин, ципрофлоксацин, пефлоксацин, ломефлоксацин. До препаратів II покоління - левофлоксацин, спарфлоксацин. Препарати III-IV поколінь: моксифлоксацин, геміфлоксацин, гатифлоксацин, ситафлоксацин, тровафлоксацин [96].

Сімейство викидних насосів транспортує безліч структурно різноманітних протимікробних субстратів. Крім того, роль насосів RND у резистентності бактерії лежить в основі багатьох інших механізмів опору. Випускні насоси RND також виконують складну багатогранну роль у базовій бактеріальній фізіології та мають вирішальне значення для здатності грамнегативних організмів викликати інфекцію. Ці важливі ролі викидних систем RND роблять їх привабливими мішенями для розробки інгібіторів викидного насоса [97].

Фторхінолони, як і інші протимікробні засоби володіють широким спектром дії, як на мікроорганізми, так і на макроорганізм [98]. У свою чергу, досліди 3 ципрофлоксацином засвідчили його вплив, як на трофічний склад таксонів нематод, так і можливість впливу на трофічні ланцюги в цілому [99].

Стійкість до фторхінолонів у мікроорганізмів може нести сезонний характер і зростає у виділених ізолятів через 1-2 місяці після введення антибіотику [100].

Фторхінолони можуть розкладатись на сонці, але продукти розкладу можуть володіти високою токсичністю [101].

На сьогодні показано, що бактерії в боротьбі з навантаженням фторхінолонами можуть використовувати паралельно два механізми, це хімічна модифікація молекули (деетилювання та гідроксилювання) та відкачування через спеціалізовані помпи у оточуюче середовище молекули антибіотичного препарату [102].

Аміноглікозиди поділяють на чотири покоління: I Стрептоміцин, Неоміцин, Канаміцин, Мономіцин; II - Гентаміцин; III - Тобраміцин, Сизоміцин, Амікацин, Нетилміцин; IV покоління - Ізепаміцин. За механізмом дії - порушення синтезу білка на бактеріальній рибосомі шляхом збирання білків 3 відмінним амінокислотним складом. Основним механізмом стійкості мікроорганізмів до аміноглікозидів окрім модифікації рибосомальних білків та білків клітинної стінки є модифікація молекули антибіотику бактеріальними аміноглікозідомодифікуючими ферментами. Модифіковані молекули аміноглікозидів шляхом їх фосфорилювання, ацетилування або аденілювання не здатні ефективно зв'язуватися з бактеріальними рибосомами і порушувати синтез білка, а отже, і життєдіяльність мікробної клітини [103].

Зареєстровано істотні відмінності в кількості та різноманітності генів AMR у неочищених стічних водах між Свропою / Північною Америкою / Океанією та Африкою / Азією / Південною Америкою. Кількість генів AMR сильно корелює 3 соціально-економічними, медичними та екологічними факторами, які використовувались для прогнозування вмісту генів AMR у всіх країнах світу [104].

Поряд з тим 3'являються технології, в яких антибіотикорезистентні властивості окремих штамів використовуються для видалення антибіотиків 3 стічних вод. Так, на прикладі хлорамфеніколу (антибіотик інгібує синтез бактеріального білка на рибосомах [105]) можна показати, як розробляються технології з обмеження його циркуляції у довкіллі. На рисунку 5 
зображено схему комбінованої утилізації хлорамфеніколу з використанням бактерій у стічних водах [106].

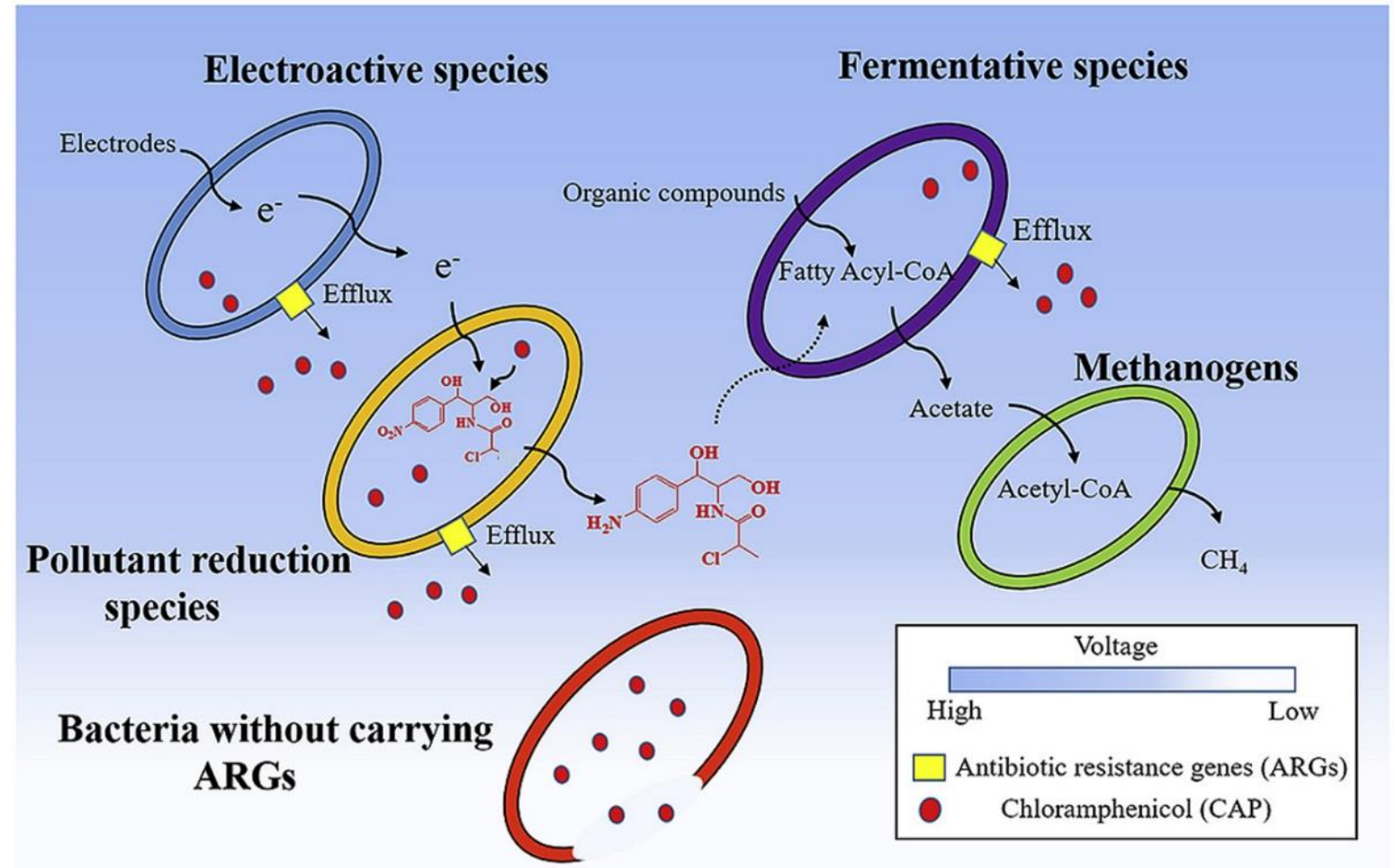

Рисунок 5. Утилізація хлорамфеніколу у стічних водах [1].

За знешкодження хлорамфеніколу відповідає 2 гени хлорамфенікол ацетилтрансфераза (CAT), фермент, відповідальний за більшу частину опосередкованої плазмідами стійкості до хлорамфеніколу що перешкоджає зв'язуванню хлорамфеніколу з рибосомною субодиницею $50 \mathrm{~S}$ шляхом його моно- та діацетилювання CAT/ каталізує перенесення ацетильної групи з ацетилCoA на Cm, утворюючи ацетильований Cm i CoASH [107-108].

Ген cmlA надає неферментативну стійкість до хлорамфеніколу за допомогою механізму відтоку. Ген E. coli flo визначає неферментативну перехресну стійкість як до флорфеніколу, так і до хлорамфеніколу, а його присутність серед коровячих ізолятів E. coli різного генетичного походження вказує на розподіл набагато ширший, ніж вважалося раніше.

Транспозон Тп9 кодує хлорамфенікол-ацетилтрансферазу (САТ) - фермент, що інактивує хлорамфенікол шляхом ацетилування. В еукаріотичних клітинах фермент не синтзується [109].

Таким чином наявні серйозні ризики, пов'язані із споживанням та переробкою молока кантамінованого антибіотиками та антибіотикорезистентними штамами мікроорганізмів.

\section{Список літератури}

1. Harding, F. (Ed.). (1995). Milk quality. New York: Blackie Academic \& Professional. https://link.springer.com/book/10.1007\%2F978-1-4615-2195-2

2. Технологія молока та молочних продуктів : навчальний посібник / Власенко В. В., Т 38 Головко М. П., Семко Т. В., Головко Т. М. - Харківський державний університет харчування та торгівлі. - Харків : ХДУХТ, 2018. - 202 с.

3. Mishra, P., Matuka, A., Abotaleb, M.S.A. et al. Modeling and forecasting of milk production in the SAARC countries and China. Model. Earth Syst. Environ. (2021). https://doi.org/10.1007/s40808$\underline{021-01138-\mathrm{Z}}$

4. Grelet, C., Dardenne, P., Soyeurt, H., Fernandez, J. A., Vanlierde, A., Stevens, F., ... \& Dehareng, F. (2021). Large-scale phenotyping in dairy sector using milk MIR spectra: Key factors affecting the quality of predictions. Methods, 186, 97-111. 
5. Schrader SM, Vaubourgeix J, Nathan C. Biology of antimicrobial resistance and approaches to combat it. Science Translational Medicine. 2020 Jun 24;12(549).

6. Arkin RL (2005) FDA newsletter: CVM researchers use latest science to develop methods for detecting animal drug residues. 2014.

7. Thi TD, Lopez E, Rodriguez-Rojas A, Rodriguez-Beltran J, Couce A, et al. (2011) Effect of recA inactivation on mutagenesis of Escherichia coli exposed to sublethal concentrations of antimicrobials. J Antimicrob Chemother 66:531-538.

8. Pereira RVV, Siler JD, Bicalho RC, Warnick LD (2014) In Vivo Selection of Resistant E. coli after Ingestion of Milk with Added Drug Residues. PLoS ONE 9(12): e115223. https://doi.org/10.1371/journal.pone.0115223.

9. Rajala-Schultz, P., Nødtvedt, A., Halasa, T., \& Persson Waller, K. (2021). Prudent Use of Antibiotics in Dairy Cows: The Nordic Approach to Udder Health. Frontiers in Veterinary Science, 8, 170.

10. Campylobacter, Salmonella spp. тa Escherichia coli . Wendie L. Claeys, Sabine Cardoen, Georges Daube, Jan De Block, Koen Dewettinck, Katelijne Dierick, Lieven De Zutter, André Huyghebaert, Hein Imberechts, Pierre Thiange, Yvan Vandenplas, Lieve Herman, 'Raw or heated cow milk consumption: Review of risks and benefits', Food Control Volume 31, Issue 1, May 2013, Pages 251-262 http://dx.doi.org/10.1016/j.foodcont.2012.09.035

11. Teh, K. H., Flint, S., Palmer, J., Andrewes, P., Bremer, P., \& Lindsay, D. (2014). Biofilm- An unrecognised source of spoilage enzymes in dairy products?. International dairy journal, 34(1), 32-40.

12. Banda, R., Nduko, J., \& Matofari, J. (2020). Bacterial Biofilm Formation in Milking Equipments in Lilongwe, Malawi. Journal of food quality and hazards control. DOI: https://doi.org/10.18502/jfqhc.7.3.4146

13. M. Barbano, Y. Ma, M.V. Santos, Influence of Raw Milk Quality on Fluid Milk Shelf Life 1, 2, Journal of Dairy Science, Volume 89, Supplement, 2006, Pages E15-E19, https://doi.org/10.3168/jds.S0022-0302(06)72360-8.Ha.

14. Metz, M., Sheehan, J., \& Feng, P. C. (2020). Use of indicator bacteria for monitoring sanitary quality of raw milk cheeses-A literature review. Food microbiology, 85, 103283.

15. World Health Organization. Antimicrobial resistance: global report on surveillance (World Health Organization, Geneva, Switzerland, 2014.

16. Oliveira, N. A., Gonçalves, B. L., Lee, S. H. I., Oliveira, C. A. F., \& Corassin, C. H. (2020). Use of antibiotics in animal production and its impact on human health. Journal of Food Chemistry and Nanotechnology, 6(01), 40-47.

17. Voitsitskiy, V.V. Danchuk, V .O. Ushkalov, S.V. Midyk, O.Yu. Kepple, O .V. Danchuk, L.V. Shevchenko, Migration of antibiotics residual quantities in aquatic ecosystems V.M. (2019), Ukrainian Journal of Ecology, 9, №3, P. 280-286.

18. Ushkalov V, Danchuk V, Midyk S, Voloshchuk N, Danchuk O. Mycotoxins in milk and in dairy products. Food science and technology. 2020;14(3):137-149. DOI: https://doi.org/10.15673/fst.v14i3.1786).

19. Godziszewska, J., Pogorzelska-Nowicka, E., Brodowska, M., Jagura-Burdzy, G., \& Wierzbicka, A. (2018). Detection in raw cow's milk of coliform bacteria-reservoir of antibiotic resistance. LWT, 93, 634-640.

20. HANKIN, Lester, et al. Antibiotic-resistant bacteria in raw milk and ability of some to transfer antibiotic resistance to Escherichia coli. Journal of food protection, 1979, 42.12: 950-953.

21. von Nussbaum F, Brands M, Hinzen B, Weigand S, Häbich D. 2006. Antibacterial natural products in medicinal chemistry--exodus or revival? Angew Chem Int Ed Engl 45(31): 5072-5129. https://doi. org/10.1002/anie.200600350

22. Chiesa LM, DeCastelli L, Nobile M, Martucci F, Mosconi G, Fontana M, Castrica M, Arioli F, Panseri S. Analysis of antibiotic residues in raw bovine milk and their impact toward food safety and on milk starter cultures in cheese-making process. LWT. 2020 Sep 1;131:109783. 
23. Quintanilla P, Beltrán MC, Molina MP, Escriche I. Enrofloxacin treatment on dairy goats: Presence of antibiotic in milk and impact of residue on technological process and characteristics of mature cheese. Food Control. 2021 May 1;123:107762.

24. Câmara SP, Dapkevicius A, Silva CC, Malcata FX, LN Enes Dapkevicius M. Artisanal Pico cheese as reservoir of Enterococcus species possessing virulence and antibiotic resistance properties: Implications for food safety. Food Biotechnology. 2020 Jan 2;34(1):25-41.

25. Abdul-Raouf U M, Ammar M S and Beuchat L R (1996) Isolation of Escherichia coli O157: H7 from some Egyptian foods. International Journal of Food Microbiology 29 423-426. ;

26. De Buyser M L, Dufour B, Maire M and Lafarge V (2001) Implication of milk and milk products in food-borne disease in France and in different industrialised countries. International Journal of Food Microbiology 67 1-17.

27. Coia, J. E., Johnston, Y., Steers, N. J., \& Hanson, M. F. (2001). A survey of the prevalence of Escherichia coli $\mathrm{O} 157$ in raw meats, raw cow's milk and raw-milk cheeses in south-east Scotland. International Journal of Food Microbiology, 66(1-2), 63-69.

28. Ombarak, R. A., Hinenoya, A., Awasthi, S. P., Iguchi, A., Shima, A., Elbagory, A. R. M., \& Yamasaki, S. (2016). Prevalence and pathogenic potential of Escherichia coli isolates from raw milk and raw milk cheese in Egypt. International Journal of Food Microbiology, 221, 69-76.

29. Hill B. et al. Microbiology of raw milk in New Zealand //International Journal of Food Microbiology. - 2012. - T. 157. - №. 2. - C. 305-308.

30. Dušková, M., Morávková, M., Mrázek, J., Florianová, M., Vorlová, L., \& Karpíšková, R. (2021). Assessment of antibiotic resistance in starter and non-starter lactobacilli of food origin. Acta Veterinaria Brno, 89(4), 401-411.

31. Tanya L Alderete, Chloe Autran, Benjamin E Brekke, Rob Knight, Lars Bode, Michael I Goran, David A Fields, Associations between human milk oligosaccharides and infant body composition in the first 6 mo of life, The American Journal of Clinical Nutrition, Volume 102, Issue 6, December 2015, Pages 1381-1388, https://doi.org/10.3945/ajcn.115.115451

32. Urbaniak, C., Angelini, M., Gloor, G.B. et al. Human milk microbiota profiles in relation to birthing method, gestation and infant gender. Microbiome 4, 1 (2016). https://doi.org/10.1186/s40168015-0145-y

33. Tanya L Alderete, Chloe Autran, Benjamin E Brekke, Rob Knight, Lars Bode, Michael I Goran, David A Fields, Associations between human milk oligosaccharides and infant body composition in the first 6 mo of life, The American Journal of Clinical Nutrition, Volume 102, Issue 6, December 2015, Pages 1381-1388, https://doi.org/10.3945/ajcn.115.115451

34. Singh, K. S., Singh, B. P., Rokana, N., Singh, N., Kaur, J., Singh, A., \& Panwar, H. (2021). Biotherapeutics from Human Milk: Prospects and Perspectives. Journal of Applied Microbiology. https://doi.org/10.1111/jam.15078

35. Alderete, T.L., Autran, C., Brekke, B.E., Knight, R., Bode, L., Goran, M.I. and Fields, D.A. (2015) Associations between human milk oligosaccharides and infant body composition in the first 6 mo of life. Am J Clin Nutr 102, 1381-1388. https://doi.org/10.3945/ajcn.115.115451

36. Martin, C.R., Ling, P.R. and Blackburn, G.L. (2016) Review of infant feeding: key features of breast milk and infant formula. Nutrients 8, 1-11. https://doi.org/10.3390/nu8050279

37. Sharma, C., Singh, B. P., Thakur, N., Gulati, S., Gupta, S., Mishra, S. K., \& Panwar, H. (2017). Antibacterial effects of Lactobacillus isolates of curd and human milk origin against food-borne and human pathogens. 3 Biotech, 7(1), 31.

38. Jamyuang, C., Phoonlapdacha, P., Chongviriyaphan, N., Chanput, W., Nitisinprasert, S., \& Nakphaichit, M. (2019). Characterization and probiotic properties of Lactobacilli from human breast milk. 3 Biotech, 9(11), 1-11

39. Sharma, C., Gulati, S., Thakur, N., Singh, B. P., Gupta, S., Kaur, S., ... \& Panwar, H. (2017). Antibiotic sensitivity pattern of indigenous lactobacilli isolated from curd and human milk samples. 3 Biotech, 7(1), 53. 
40. Heikkila MP, Saris PEJ. Inhibition of Staphylococcus aureus by the commensal bacteria of human milk. J Appl Microbiol. 2003;95(3):471-8. 10.1046/j.1365-2672.2003.02002.x

41. Yadav M, Shukla P. Efficient engineered probiotics using synthetic biology approaches: a review. Biotechnology and applied biochemistry. 2020 Jan;67(1):22-9.

42. Otto M. Staphylococcus epidermidis-The "accidental" pathogen. Nat Rev Microbiol. 2009; 7(8):555-67. 10.1038/nrmicro2182.

43. Moles, L., Gómez, M., Moroder, E., Bustos, G., Melgar, A., Del Campo, R., \& Rodríguez, J. M. (2020). Staphylococcus epidermidis in feedings and feces of preterm neonates. Plos one, 15(2), $\mathrm{e} 0227823$.

44. Moles L, Gómez M, Heilig H, Bustos G, Fuentes S, de Vos W, et al. Bacterial Diversity in Meconium of Preterm Neonates and Evolution of Their Fecal Microbiota during the First Month of Life. PLoS One. 2013;8(6).

45. Honi, U., Sabrin, F., Islam, T., Islam, M., Billah, M., \& Islam, K. D. (2021). Enzymatic activity and antibiotic resistance profile of Lactobacillus paracasei ssp. paracasei-1 isolated from regional yogurts of Bangladesh. Journal of Microbiology, Biotechnology and Food Sciences, 2021, 235-239.

46. R.M. Kamal, M.E. Alnakip, S.F. Abd El Aal, M.A. Bayoumi Bio-controlling capability of probiotic strain Lactobacillus rhamnosus against some common foodborne pathogens in yoghurt Int. Dairy J., 85 (2018), pp. 1-7 https://doi.org/10.1016/j.idairyj.2018.04.007

47. Qian, Z., Zhao, D., Yin, Y., Zhu, H., \& Chen, D. (2020). Antibacterial activity of lactobacillus strains isolated from Mongolian yogurt against Gardnerella vaginalis. BioMed research international, 2020. https://doi.org/10.1155/2020/3548618

48. Aziz, G., Zaidi, A., Bakht, U., Parveen, N., Ahmed, I., Haider, Z., \& Muhammad, T. (2020). Microbial safety and probiotic potential of packaged yogurt products in Pakistan. Journal of Food Safety, 40(1), e12741.

49. AARESTRUP, Frank M. The livestock reservoir for antimicrobial resistance: a personal view on changing patterns of risks, effects of interventions and the way forward. Philosophical Transactions of the Royal Society B: Biological Sciences, 2015, 370.1670: 20140085.

50. Tóth, A.G., Csabai, I., Krikó, E. et al. Antimicrobial resistance genes in raw milk for human consumption. Sci Rep 10, 7464 (2020). https://doi.org/10.1038/s41598-020-63675-4

51. Centers for Disease Control and Prevention. Antibiotic Resistance Threats in the United States (U.S. Department of Health and Human Services, CDC, Atlanta, GA, USA, 2019.

52. Tóth, A.G., Csabai, I., Krikó, E. et al. Antimicrobial resistance genes in raw milk for human consumption. Sci Rep 10, 7464 (2020). https://doi.org/10.1038/s41598-020-63675-4.

53. García-Galán, A., Nouvel, L. X., Baranowski, E., Gómez-Martín, Á., Sánchez, A., Citti, C., \& de la Fe, C. (2020). Mycoplasma bovis in Spanish cattle herds: Two groups of multiresistant isolates predominate, with one remaining susceptible to fluoroquinolones. Pathogens, 9(7), 545.

54. V. Saini, J.T. McClure, D. Léger, S. Dufour, A.G. Sheldon, D.T. Scholl, H.W. Barkema, Antimicrobial use on Canadian dairy farms, Journal of Dairy Science, Volume 95, Issue 3, 2012, Pages 1209-1221, ISSN 0022-0302,

https://doi.org/10.3168/jds.2011-4527. http://www.sciencedirect.com/science/article/pii/S002203021200080X

55. P.N. Tempini, S.S. Aly, B.M. Karle, R.V. Pereira, Multidrug residues and antimicrobial resistance patterns in waste milk from dairy farms in Central California, Journal of Dairy Science, Volume 101, Issue 9, 2018, Pages 8110-8122, ISSN 0022-0302, https://doi.org/10.3168/jds.2018-14398. http://www.sciencedirect.com/science/article/pii/S0022030218306246 )).

56. Otto, M. (2009). Staphylococcus epidermidis - the'accidental'pathogen. Nature reviews microbiology, 7(8), 555-567.

57. Qin, L., Da, F., Fisher, E. L., Tan, D. C., Nguyen, T. H., Fu, C. L., ... \& Otto, M. (2017). Toxin mediates sepsis caused by methicillin-resistant Staphylococcus epidermidis. PLoS Pathogens, 13(2), e1006153. 
58. Abbondio, M., Fois, I., Longheu, C., Azara, E., \& Tola, S. (2019). Biofilm production, quorum sensing system and analysis of virulence factors of Staphylococcus epidermidis collected from sheep milk samples. Small Ruminant Research, 174, 83-87.

59. Wu, J. A., Kusuma, C., Mond, J. J., \& Kokai-Kun, J. F. (2003). Lysostaphin disrupts Staphylococcus aureus and Staphylococcus epidermidis biofilms on artificial surfaces. Antimicrobial agents and chemotherapy, 47(11), 3407-3414.

60. Tran P, Prindle A. Synthetic biology in biofilms: Tools, challenges, and opportunities. Biotechnology Progress.:e3123. Weber M, Liedtke J, Plattes S, Lipski A (2019) Bacterial community composition of biofilms in milking machines of two dairy farms assessed by a combination of culturedependent and -independent methods. PLoS ONE 14(9): e0222238. https://doi.org/10.1371/journal.pone.0222238).

61. Namvar, A. E., Bastarahang, S., Abbasi, N., Ghehi, G. S., Farhadbakhtiarian, S., Arezi, P., ... \& Chermahin, S. G. (2014). Clinical characteristics of Staphylococcus epidermidis: a systematic review. GMS hygiene and infection control, 9(3).

62. Otto, M. (2009). Staphylococcus epidermidis - the'accidental'pathogen. Nature reviews microbiology, 7(8), 555-567.

63. Gomes, F., Teixeira, P., \& Oliveira, R. (2014). Mini-review: Staphylococcus epidermidis as the most frequent cause of nosocomial infections: old and new fighting strategies. Biofouling, 30(2), 131141.

64. Turchi, B., Bertelloni, F., Marzoli, F., Cerri, D., Tola, S., Azara, E., ... \& Fratini, F. (2020). Coagulase negative staphylococci from ovine milk: Genotypic and phenotypic characterization of susceptibility to antibiotics, disinfectants and biofilm production. Small Ruminant Research, 183, 106030.

65. Cheema, A. S., Stinson, L. F., Lai, C. T., Geddes, D. T., \& Payne, M. S. (2021). DNA extraction method influences human milk bacterial profiles. Journal of Applied Microbiology, 130(1), 142-156.

66. Fisher, E. A., \& Paterson, G. K. (2020). Prevalence and characterisation of methicillin-resistant staphylococci from bovine bulk tank milk in England and Wales. Journal of global antimicrobial resistance, 22, 139-144.

67. Dong Y, Speer CP. The role of Staphylococcus epidermidis in neonatal sepsis: Guarding angel or pathogenic devil? Int J Med Microbiol. 2014;304(5-6):513-20. 10.1016/j.ijmm.2014.04.013

68. Baylis, C. L. (2009). Raw milk and raw milk cheeses as vehicles for infection by Verocytotoxin-producing Escherichia coli. International Journal of Dairy Technology, 62(3), 293-307.

69. Keseler IM, Collado-Vides J, Santos-Zavaleta A, Peralta-Gil M, Gama-Castro S, MuñizRascado L, Bonavides-Martinez C, Paley S, Krummenacker M, Altman T, Kaipa P. EcoCyc: a comprehensive database of Escherichia coli biology. Nucleic acids research. 2010 Nov 20;39(supp1_1):D583-90.

70. Menge C. Molecular biology of Escherichia coli Shiga toxins' effects on mammalian cells. Toxins. 2020 May;12(5):345.

71. Baylis, C. L. (2009). Raw milk and raw milk cheeses as vehicles for infection by Verocytotoxin-producing Escherichia coli. International Journal of Dairy Technology, 62(3), 293-307.

72. Ombarak, R. A., Hinenoya, A., Awasthi, S. P., Iguchi, A., Shima, A., Elbagory, A. R. M., \& Yamasaki, S. (2016). Prevalence and pathogenic potential of Escherichia coli isolates from raw milk and raw milk cheese in Egypt. International Journal of Food Microbiology, 221, 69-76.

73. Coia, J. E., Johnston, Y., Steers, N. J., \& Hanson, M. F. (2001). A survey of the prevalence of Escherichia coli $\mathrm{O} 157$ in raw meats, raw cow's milk and raw-milk cheeses in south-east Scotland. International Journal of Food Microbiology, 66(1-2), 63-69.

74. Dhaka P, Vijay D, Vergis J, Negi M, Kumar M, Mohan V, Doijad S, Poharkar KV, Malik SS, Barbuddhe SB. Genetic diversity and antibiogram profile of diarrhoeagenic Escherichia coli pathotypes 
isolated from human, animal, foods and associated environmental sources. Infection Ecol \& Epidemiol. 2016;6:31055.

75. Dhaka P, Vijay D, Vergis J, Negi M, Kumar M, Mohan V, Doijad S, Poharkar KV, Malik SS, Barbuddhe SB. Genetic diversity and antibiogram profile of diarrhoeagenic Escherichia coli pathotypes isolated from human, animal, foods and associated environmental sources. Infection Ecol \& Epidemiol. 2016;6:31055.

76. Wang J, Stanford K, McAllister TA, Johnson RP, Chen J, Hou H, Zhang G, Niu YD. Biofilm formation, virulence gene profiles, and antimicrobial resistance of nine serogroups of non-O157 Shiga toxin-producing Escherichia coli. Foodborne Pathog Dis. 2016;13:316-24.

77. Farshad S, Ranijbar R, Japoni A, Hosseini M, Anvarinejad M, Mohammadzadegan R. Microbial susceptibility, virulence factors, and plasmid profiles of uropathogenic Escherichia coli strains isolated from children in Jahrom, Iran. Archives of Iranian Medicine (AIM). 2012;15:312-6.

78. Momtaz H, Farzan R, Rahimi E, Safarpoor Dehkordi F, Souod N. Molecular characterization of Shiga toxin-producing Escherichia coli isolated from ruminant and donkey raw milk samples and traditional dairy products in Iran. Sci World J. 2012;2012:1-13

79. Momtaz H, Dehkordi FS, Rahimi E, Ezadi H, Arab R. Incidence of Shiga toxin-producing Escherichia coli serogroups in ruminant's meat. Meat Sci. 2013;95:381-8.

80. Amézquita-López BA, Quiñones B, Soto-Beltrán M, Lee BG, Yambao JC, Lugo-Melchor OY, Chaidez C. Antimicrobial resistance profiles of Shiga toxin-producing Escherichia coli O157 and nonO157 recovered from domestic farm animals in rural communities in northwestern Mexico. Antimicrob Resist Infect Control. 2016;5:1

81. Momtaz H, Farzan R, Rahimi E, Safarpoor Dehkordi F, Souod N. Molecular characterization of Shiga toxin-producing Escherichia coli isolated from ruminant and donkey raw milk samples and traditional dairy products in Iran. Sci World J. 2012;2012:1-13.

82. Momtaz H, Dehkordi FS, Rahimi E, Ezadi H, Arab R. Incidence of Shiga toxin-producing Escherichia coli serogroups in ruminant's meat. Meat Sci. 2013;95:381-8

83. Dehkordi FS, Yazdani F, Mozafari J, Valizadeh Y. Virulence factors, serogroups and antimicrobial resistance properties of Escherichia coli strains in fermented dairy products. BMC

84. Momtaz H, Farzan R, Rahimi E, Safarpoor Dehkordi F, Souod N. Molecular characterization of Shiga toxin-producing Escherichia coli isolated from ruminant and donkey raw milk samples and traditional dairy products in Iran. Sci World J. 2012;2012:1-13

85. Momtaz H, Safarpoor Dehkordi F, Rahimi E, Ezadi H, Arab R. Incidence of Shiga toxinproducing Escherichia coli serogroups in ruminant's meat. Meat Sci. 2013 Oct;95(2):381-8. doi: 10.1016/j.metsci.2013.04.051. Epub 2013 May 1. PMID: 23747633.

86. Dehkordi FS, Yazdani F, Mozafari J, Valizadeh Y. Virulence factors, serogroups and antimicrobial resistance properties of Escherichia coli strains in fermented dairy products. BMC research notes. $2014 ; 7: 217$

87. Martínez, J. L. (2008). Antibiotics and antibiotic resistance genes in natural environments. Science, 321(5887), 365-367.]. Starikova, E. V., Prianichnikov, N. A., Zdobnov, E., Govorun, V. M. (2017). Bioinformatics analysis of antimicrobial resistance genes and prophages colocalized in human gut metagenomes. Biomeditsinskaya khimiya, 63(6), 508-512.].

88. Terence S. Crofts, Pratyush Sontha, Amber O. King, Bin Wang, Brent A. Biddy, Nicole Zanolli, John Gaumnitz, Gautam Dantas, Discovery and Characterization of a Nitroreductase Capable of Conferring Bacterial Resistance to Chloramphenicol, Cell Chemical Biology, Volume 26, Issue 4, 2019, Pages 559-570.e6, ISSN 2451-9456, https://doi.org/10.1016/j.chembiol.2019.01.007.

89. Kevin J. Forsberg, Sanket Patel, Timothy A. Wencewicz, Gautam Dantas, The Tetracycline Destructases: A Novel Family of Tetracycline-Inactivating Enzymes, Chemistry \& Biology, Volume 22, Issue 7, 2015, Pages 888-897, ISSN 1074-5521, https://doi.org/10.1016/j.chembiol.2015.05.017.

90. Chukwudi CU. 2016. rRNA binding sites and the molecular mechanism of action of the tetracyclines. Antimicrob Agents Chemother 60:4433-4441. doi:10.1128/AAC.00594-16 
91. Functionalized Single-Walled Carbon Nanotubes and Nanographene Oxide to Overcome Antibiotic Resistance in Tetracycline-Resistant Escherichia coli Jordan A. Carver, Audrey L. Simpson, Ria P. Rathi... and Mark D. Ellison ACS Applied Nano Materials 20203 (4), 3910-3921 DOI: 10.1021/acsanm.0c00677.

92. Roemhild R, Linkevicius M, Andersson DI (2020) Molecular mechanisms of collateral sensitivity to the antibiotic nitrofurantoin. PLoS Biol 18(1): e3000612. https://doi.org/10.1371/journal.pbio.3000612

93. Shakti L, Veeraraghavan B. Advantage and limitations of nitrofurantoin in multi-drug resistant Indian scenario. Indian Journal of Medical Microbiology. 2015 Oct 1;33(4):477.

94. Osei Sekyere J. Genomic insights into nitrofurantoin resistance mechanisms and epidemiology in clinical Enterobacteriaceae //Future science OA. - 2018. - T. 4. - №. 5. - C. FSO293.

95. Sorlozano-Puerto, A., Lopez-Machado, I., Albertuz-Crespo, M., Martinez-Gonzalez, L. J., \& Gutierrez-Fernandez, J. (2020). Characterization of fosfomycin and nitrofurantoin resistance mechanisms in Escherichia coli isolated in clinical urine samples. Antibiotics, 9(9), 534.

96. Яковлєва, Л. В., Яковлева, Л. В., Бердник, О. Г., \& Кривозуб, І. О. (2018). Аналіз українського фармацевтичного ринку антибіотиків групи фторхінолонів http://91.234.42.22/bitstream/123456789/18172/1/197-199.pdf

97. Colclough, A. L., Alav, I., Whittle, E. E., Pugh, H. L., Darby, E. M., Legood, S. W., ... \& Blair, J. M. (2020). RND efflux pumps in Gram-negative bacteria; regulation, structure and role in antibiotic resistance. Future Microbiology, 15(2), 143-157. https://doi.org/10.2217/fmb-2019-0235

98. Assar, S., Nosratabadi, R., Masoumi, J., Mohamadi, M., \& Hassanshahi, G. (2020). A Review of Immunomodulatory Effects of Fluoroquinolones. Immunological Investigations, 1-20 https://doi.org/10.1080/08820139.2020.1797778

99. Ahmed Nasri, Mohamed Allouche, Amel Hannachi, Taha Barkaoui, Badreddine Barhoumi, Ibtihel Saidi, Fabio D'Agostino, Ezzeddine Mahmoudi, Hamouda Beyrem, Fehmi Boufahja, Nematodes trophic groups changing via reducing of bacterial population density after sediment enrichment to ciprofloxacin antibiotic: Case study of Marine Mediterranean community, Aquatic Toxicology, Volume 228, 2020, C. 105632, ISSN 0166-445X, https://doi.org/10.1016/j.aquatox.2020.105632.

100.Jean-Paul R Soucy, Alexandra M Schmidt, Caroline Quach, David L Buckeridge, Fluoroquinolone Use and Seasonal Patterns of Ciprofloxacin Resistance in Community-Acquired Urinary Escherichia coli Infection in a Large Urban Center, American Journal of Epidemiology, Volume 189, Issue 3, March 2020, Pages 215-223, https://doi.org/10.1093/aje/kwz239

101.Zelmat, Y., Rousseau, V., Chebane, L. et al. Fluoroquinolone-Induced Photosensitivity: A Chemical Fragment-Based Approach by a Case/Non-case Study in VigiBase ${ }^{\circledR}$. Drug Saf 43, 561-566 (2020). https://doi.org/10.1007/s40264-020-00917-4

102.Jia, Y., Khanal, S. K., Shu, H., Zhang, H., Chen, G. H., \& Lu, H. (2018). Ciprofloxacin degradation in anaerobic sulfate-reducing bacteria (SRB) sludge system: mechanism and pathways. Water research, 136, 64-74.

103. Kelly C. Wade, Daniel K. Benjamin, CHAPTER 37 - Clinical Pharmacology of Anti-Infective Drugs, Editor(s): Jack S. Remington, Jerome O. Klein, Christopher B. Wilson, Victor Nizet, Yvonne A. Maldonado, Infectious Diseases of the Fetus and Newborn (Seventh Edition), W.B. Saunders, 2011, Pages 1160-1211, ISBN 9781416064008, https://doi.org/10.1016/B978-1-4160-6400-8.00037-7

104.HENDRIKSEN, Rene S., et al. Global monitoring of antimicrobial resistance based on metagenomics analyses of urban sewage. Nature communications, 2019, 10.1: 1-12.

105.Choi, J., Marks, J., Zhang, J. et al. Dynamics of the context-specific translation arrest by chloramphenicol and linezolid. Nat Chem Biol 16, 310-317 (2020). https://doi.org/10.1038/s41589-019$\underline{0423-2}$

106. Mechanisms of metabolic performance enhancement during electrically assisted anaerobic treatment of chloramphenicol wastewater Author: Ning Guo,Xiaofang Ma,Shaojie Ren,Shuguang 
Wang,Yunkun Wang Publication: Water Research Publisher: Elsevier Date: 1 June 2019 https://doi.org/10.1016/j.watres.2019.03.032

107. Keyes K, Hudson C, Maurer JJ, Thayer S, White DG, Lee MD. Detection of florfenicol resistance genes in Escherichia coli isolated from sick chickens. Antimicrob Agents Chemother. 2000 Feb;44(2):421-4. doi: 10.1128/aac.44.2.421-424.2000. PMID: 10639375; PMCID: PMC89696.

108. Cannon M, Harford S, Davies J. A comparative study on the inhibitory actions of chloramphenicol, thiamphenicol and some fluorinated derivatives. J Antimicrob Chemother. 1990 Sep;26(3):307-17. doi: 10.1093/jac/26.3.307. PMID: 2228823.

109. White, D. G., Hudson, C., Maurer, J. J., Ayers, S., Zhao, S., Lee, M. D., \& SHERWOOD, J. (2018). Chloramphenicol and Florfenicol Resistance in Escherichia Coli of Characterization. Sci J of Ani and Vet Sci, 1(1), 001-006.

\section{ANTIBIOTICS AND ANTIBIOTIC RESISTANT PROPERTIES OF MILK MICROORGANISMS \\ V. Danchuk, V. Trach, T. Prystupa, M. Klyutsuk, V. Dobrovolsky, L. Savchuk,} A. Levchenko, O. Danchuk

The review presents scientifically substantiated data on the risks associated with the consumption and processing of milk contaminated with antibiotics and antibiotic-resistant strains of microorganisms.

Key words: antibiotics, antibiotic resistance, milk.

\section{АНТИБИОТИКИ И АНТИБИОТИКОРЕЗИСТЕНТНЫЕ СВОЙСТВА МИКРООРГАНИЗМОВ МОЛОКА}

В. Данчук, В. Трач, Т. Приступа, М. Клюцук, В. Добровольский, Л. Савчук, А. Левченко, А. Данчук

В обзоре представлены научно обоснованные данные о рисках, связанных с потреблением и переработкой молока кантаминованого антибиотиками и антибиотикорезистентными итаммами микроорганизмов.

Ключевые слова: антибиотики, антибиотикорезистентнисть, молоко. 